\title{
Humanização no Tratamento Penal de Menores em Conflito com a Lei Acometidos de Transtornos Mentais
}

\author{
Chaves, Anna Cecília Santos \\ Universidade de São Paulo — acschaves@yahoo.com.br
}

Menores de 18 anos são, por definição legal, inimputáveis, ou seja, submetem-se a um tratamento jurídico-penal especial, consubstanciado no Estatuto da Criança e do Adolescente. Ocorre que, para menores acometidos de transtornos mentais, o mencionado diploma legal não prevê resposta penal similar à medida de segurança, que destina-se a maiores de 18 anos considerados semi-inimputáveis ou inimputáveis. a lei limita-se a prever apenas a possibilidade de requisição de tratamento médico, psicológico ou psiquiátrico, em regime hospitalar ou ambulatorial. Não há, no entanto, formalmente instituídas, instituições apartada daquelas nas quais são cumpridas as medidas sócioeducativas, em sua espécie internação, na qual um menor em conflito com a lei, mas acometido de um transtorno psiquiátrico diretamente relacionado a sua conduta, poderia valer-se de tratamento médico, psiquiátrico e/ou psicológico adequados à sua condição. Essa lacuna, não apenas legal, mas também e principalmente, estrutural, é conflitante com a atual política nacional que rege os sistemas de saúde, cujo princípio estruturante é a humanização dos serviços de saúde, não apenas para seus beneficiários, como também para seus gestores e funcionários. Neste trabalho serão destacadas experiências que se propuseram a fornecer uma resposta a essa questão central, como a Unidade Experimental de Saúde, no Estado de São Paulo, verificando-se, de maneira objetiva, o contexto de sua criação e sua finalidade, o número exato de internos, o diagnóstico psiquiátrico que ensejou a internação dos mesmos na referida unidade, os delitos por eles cometidos e sua situação jurídica em face de seu diagnóstico, de sua periculosidade (na acepção pericial do termo) e das disposições legais vigentes. Desse modo, será verificado se e como menores poderiam se beneficiar de um tratamento adequado à sua específica situação de saúde, tecendo-se uma proposta com aptidão a suprimir a falha do sistema penal hodiernamente vigente.

Chaves, Anna Cecília Santos. Humanização no Tratamento Penal de Menores em Conflito com a Lei Acometidos de Transtornos Mentais. In: Anais do Congresso Internacional de Humanidades \& Humanização em Saúde [= Blucher Medical Proceedings, num.2, vol.1]. São Paulo: Editora Blucher, 2014. ISSN 2357-7282

DOI 10.5151/medpro-cihhs-10837 